\title{
28 Research Square \\ Quantification and Trend Analysis of Multidecadal Global Dissolved Oxygen Changes
}

\author{
Ayush Agrawal \\ Canyon Crest Academy https://orcid.org/0000-0002-1477-3085 \\ James Swift ( $\nabla$ jswift@ucsd.edu ) \\ UCSD
}

Article

Keywords:

Posted Date: December 20th, 2021

DOI: https://doi.org/10.21203/rs.3.rs-1105055/v1

License: (c) (i) This work is licensed under a Creative Commons Attribution 4.0 International License.

Read Full License 


\section{Abstract}

Previous studies have found there to be measurable deoxygenation in regions of the world's oceans, with changes linked to biogeochemical cycles, changes in ocean productivity, and climate fluctuations. Here, we investigated multidecadal large-scale dissolved oxygen trends in the principal basins of the Atlantic, Pacific, and Indian Oceans using data from WOCE, CLIVAR, and GO-SHIP cruises, representing some of the highest quality available water column data. We differenced spatially coincident older and more recent data, averaged differences in geographic subregions, and integrated results on 500-dbar thick layers from $500 \mathrm{dbar}$ to $3500 \mathrm{dbar}$, with bottom levels extending to $6000 \mathrm{dbar}$. Overall, we found a deoxygenation below $500 \mathrm{dbar}$ across all major basins at a global average rate of $-0.06 \mu \mathrm{mol} \mathrm{kg}{ }^{-1}$ year $^{-1}$, with important variations between regions and layers. Our research demonstrates a deoxygenation trend coincident with the global ocean warming and increased stratification trends documented in other studies.

\section{Introduction}

Interactions between air-sea exchange, ocean circulation, and biological factors control the distribution of dissolved oxygen in the ocean interior. Dissolved oxygen content (DO) in the oceans is known to be linked to stratification, productivity, nutrient and carbon cycling, and marine habitats. An exponential increase in 'dead zones,' areas with critically low DO, has been observed since the 1960s, leading to increased stresses on marine ecosystems [1]. Deoxygenation in major world ocean basins is correlated with global temperature changes [2][3], not just because oxygen is less soluble in warmer water but also because warming may increase upper ocean stratification [4], reducing the oxygen supply to the ocean interior. Elevated temperatures might also further contribute to positive deoxygenation feedback loops, including the oxidation of methane from deep-sea hydrates [5], accelerated respiration of dissolved organic matter [6], and high-latitude freshening [7].

Among these aforementioned factors, deoxygenation is primarily affected by stratification and subsequently decreased deep ocean convection, which is especially important in the context of climate change and future predictive models [8][9]. While biological consumption is one commonly suggested reason, a report by the IPCC observes this to be an unlikely explanation for deoxygenation over large spatial scales [10].

Deoxygenation trends may become amplified if the current rates of GHG-associated climate change continue [11], serving as potential climatic tipping points with implications for marine ecosystems and oceanic processes [12]. Studies have observed consistent deoxygenation in all major ocean basins since the 1970s [7], including the North Pacific [4], North Atlantic [13], and intermediate waters in the South Indian Ocean [3]. In addition to observational studies, models predict an estimated 1-7\% decrease in DO by 2100 , and continued deoxygenation for hundreds of years in the future [4]. While uncertainty remains, these studies suggest global deoxygenation at least during the last 40 years. 
In this article, we carefully examine high quality repeated DO data between 1983 and 2019, focusing on the World Ocean Circulation Experiment (WOCE), Climate and Ocean - Variability, Predictability, and Change (CLIVAR) repeat hydrography, and the Global Ocean Ship-based Hydrographic Investigations Program (GO-SHIP). We use these with a distinct approach to determine inferred mean DO rate of change in $500 \mathrm{dbar}$ thick layers in geographic subregions of the Atlantic, Pacific, and Indian Oceans, between 500 and $6000 \mathrm{dbar}$, excluding the upper $500 \mathrm{dbar}$ due to unresolved seasonality in the data. Deeper ocean waters are more suitable for decadal-scale analysis [9] and have not been comprehensively examined in past studies, especially on global oceanic scales, due to those studies' upper-ocean foci [14][15] centered along thermoclines [16]. We compare our findings to other established studies, primarily those of Helm et al. [7] and Schmidtko et al. [17].

\section{Results}

All specific oxygen concentration values discussed in this section can be found in Table 1, which is found at the end of this article. 
Table 1

\begin{tabular}{|c|c|c|c|c|c|c|c|c|}
\hline Basin & Subsection & $\begin{array}{l}500- \\
1000\end{array}$ & $\begin{array}{l}1000- \\
1500\end{array}$ & $\begin{array}{l}1500- \\
2000\end{array}$ & $\begin{array}{l}2000- \\
2500\end{array}$ & $\begin{array}{l}2500- \\
3000\end{array}$ & $\begin{array}{l}3000- \\
3500\end{array}$ & $\begin{array}{l}3500- \\
\text { Bottom }\end{array}$ \\
\hline \multirow[t]{11}{*}{$\begin{array}{l}\mathrm{N} \text {. } \\
\text { Atlantic }\end{array}$} & $\begin{array}{l}\text { Northwest North } \\
\text { Atlantic }\end{array}$ & -0.160 & -0.404 & -0.538 & -0.277 & -0.062 & 0.032 & -0.034 \\
\hline & $\begin{array}{l}\text { Northeast North } \\
\text { Atlantic }\end{array}$ & -0.317 & 0.083 & -0.194 & -0.047 & 0.000 & -0.048 & -0.062 \\
\hline & $\begin{array}{l}\text { North Central North } \\
\text { Atlantic }\end{array}$ & 0.151 & 0.310 & -0.232 & -0.395 & -0.083 & -0.066 & -0.086 \\
\hline & West North Atlantic & -0.012 & 0.439 & 0.038 & 0.038 & 0.034 & 0.043 & -0.028 \\
\hline & $\begin{array}{l}\text { Central North } \\
\text { Atlantic }\end{array}$ & -0.104 & 0.198 & -0.055 & -0.046 & -0.031 & -0.037 & -0.045 \\
\hline & East North Atlantic & -0.094 & 0.044 & -0.014 & -0.048 & -0.065 & -0.053 & -0.044 \\
\hline & Caribbean & -0.306 & -0.144 & -0.007 & -0.021 & -0.033 & -0.059 & -0.094 \\
\hline & $\begin{array}{l}\text { West Tropical North } \\
\text { Atlantic }\end{array}$ & -0.046 & -0.163 & -0.187 & -0.102 & -0.124 & -0.083 & -0.090 \\
\hline & $\begin{array}{l}\text { Central Tropical } \\
\text { North Atlantic }\end{array}$ & -0.176 & -0.125 & -0.235 & -0.081 & -0.071 & -0.057 & -0.062 \\
\hline & $\begin{array}{l}\text { East Tropical } \\
\text { Atlantic }\end{array}$ & -0.084 & -0.111 & -0.230 & -0.117 & -0.085 & -0.064 & -0.056 \\
\hline & Average & -0.115 & 0.013 & -0.165 & -0.110 & -0.052 & -0.039 & -0.060 \\
\hline \multirow[t]{7}{*}{$\begin{array}{l}\text { S. } \\
\text { Atlantic }\end{array}$} & $\begin{array}{l}\text { West Central South } \\
\text { Atlantic }\end{array}$ & -0.174 & -0.224 & -0.169 & -0.119 & -0.125 & -0.142 & -0.095 \\
\hline & $\begin{array}{l}\text { East Central South } \\
\text { Atlantic }\end{array}$ & -0.133 & -0.225 & -0.137 & -0.154 & -0.132 & -0.105 & -0.132 \\
\hline & $\begin{array}{l}\text { South Central } \\
\text { South Atlantic }\end{array}$ & -0.378 & -0.241 & -0.238 & -0.164 & -0.116 & -0.104 & -0.101 \\
\hline & $\begin{array}{l}\text { Southeast South } \\
\text { Atlantic }\end{array}$ & -0.334 & -0.247 & -0.127 & -0.100 & -0.103 & -0.132 & -0.122 \\
\hline & $\begin{array}{l}\text { Farsouth South } \\
\text { Atlantic }\end{array}$ & -0.211 & -0.158 & -0.153 & -0.066 & -0.101 & -0.092 & 0.000 \\
\hline & Weddell & -0.124 & -0.169 & -0.309 & -0.118 & 0.098 & -0.066 & -0.272 \\
\hline & Average & -0.226 & -0.211 & -0.189 & -0.120 & -0.080 & -0.107 & -0.120 \\
\hline \multirow{2}{*}{$\begin{array}{l}\text { N. } \\
\text { Pacific }\end{array}$} & Bering & -0.165 & 0.060 & 0.040 & 0.010 & -0.029 & -0.048 & 0.065 \\
\hline & $\begin{array}{l}\text { Northwest North } \\
\text { Pacific }\end{array}$ & -0.307 & -0.086 & -0.035 & -0.025 & -0.057 & -0.069 & -0.088 \\
\hline
\end{tabular}




\begin{tabular}{|c|c|c|c|c|c|c|c|c|}
\hline \multirow[t]{8}{*}{ Basin } & Subsection & $\begin{array}{l}500- \\
1000\end{array}$ & $\begin{array}{l}1000- \\
1500\end{array}$ & $\begin{array}{l}1500- \\
2000\end{array}$ & $\begin{array}{l}2000- \\
2500\end{array}$ & $\begin{array}{l}2500- \\
3000\end{array}$ & $\begin{array}{l}3000- \\
3500\end{array}$ & $\begin{array}{l}3500- \\
\text { Bottom }\end{array}$ \\
\hline & $\begin{array}{l}\text { North Central North } \\
\text { Pacific }\end{array}$ & -0.157 & -0.075 & -0.079 & -0.098 & -0.077 & -0.057 & -0.050 \\
\hline & $\begin{array}{l}\text { Northeast North } \\
\text { Pacific }\end{array}$ & -0.224 & -0.063 & -0.005 & 0.018 & 0.028 & 0.007 & -0.033 \\
\hline & $\begin{array}{l}\text { Far West North } \\
\text { Pacific }\end{array}$ & -0.247 & -0.243 & -0.224 & -0.057 & -0.053 & -0.091 & -0.069 \\
\hline & $\begin{array}{l}\text { West Central North } \\
\text { Pacific }\end{array}$ & -0.264 & 0.018 & 0.005 & -0.006 & -0.015 & -0.023 & -0.043 \\
\hline & $\begin{array}{l}\text { East Central North } \\
\text { Pacific }\end{array}$ & -0.221 & -0.042 & -0.021 & -0.047 & -0.074 & -0.049 & -0.044 \\
\hline & $\begin{array}{l}\text { Far East North } \\
\text { Pacific }\end{array}$ & -0.104 & -0.056 & -0.068 & -0.055 & -0.052 & -0.064 & -0.041 \\
\hline & Average & -0.211 & -0.061 & -0.048 & -0.033 & -0.041 & -0.049 & -0.038 \\
\hline \multirow[t]{12}{*}{$\begin{array}{l}\text { S. } \\
\text { Pacific }\end{array}$} & $\begin{array}{l}\text { West Tropical } \\
\text { Pacific }\end{array}$ & 0.119 & -0.027 & -0.047 & 0.025 & 0.006 & 0.004 & -0.023 \\
\hline & $\begin{array}{l}\text { Central Tropical } \\
\text { Pacific }\end{array}$ & 0.134 & -0.044 & -0.028 & -0.032 & -0.011 & -0.013 & -0.075 \\
\hline & $\begin{array}{l}\text { East Tropical } \\
\text { Pacific }\end{array}$ & 0.024 & 0.059 & 0.024 & -0.005 & -0.025 & -0.034 & -0.044 \\
\hline & $\begin{array}{l}\text { Northwest South } \\
\text { Pacific }\end{array}$ & 0.306 & 0.089 & -0.022 & -0.037 & -0.039 & -0.033 & -0.017 \\
\hline & $\begin{array}{l}\text { Central South } \\
\text { Pacific }\end{array}$ & 0.143 & 0.096 & 0.015 & 0.002 & -0.009 & -0.035 & -0.067 \\
\hline & $\begin{array}{l}\text { Northeast South } \\
\text { Pacific }\end{array}$ & 0.016 & 0.104 & 0.032 & -0.026 & 0.025 & 0.021 & -0.019 \\
\hline & East South Pacific & -0.314 & -0.099 & 0.001 & -0.004 & 0.008 & -0.005 & -0.067 \\
\hline & $\begin{array}{l}\text { Southwest South } \\
\text { Pacific }\end{array}$ & -0.019 & 0.075 & 0.000 & -0.026 & -0.035 & -0.043 & -0.061 \\
\hline & $\begin{array}{l}\text { Southeast South } \\
\text { Pacific }\end{array}$ & -0.236 & -0.020 & -0.002 & 0.018 & 0.017 & -0.015 & -0.077 \\
\hline & $\begin{array}{l}\text { Farsouth South } \\
\text { Pacific }\end{array}$ & 0.002 & -0.035 & -0.053 & -0.057 & -0.078 & -0.215 & -0.285 \\
\hline & Drake & -0.659 & -0.326 & -0.247 & -0.333 & -0.364 & -0.335 & -0.257 \\
\hline & $\begin{array}{l}\text { Average (w/o } \\
\text { Drake) }\end{array}$ & 0.017 & 0.020 & -0.008 & -0.014 & -0.014 & -0.037 & -0.073 \\
\hline Indian & West North Indian & -0.050 & -0.022 & -0.128 & -0.099 & -0.076 & -0.068 & -0.017 \\
\hline
\end{tabular}




\begin{tabular}{|c|c|c|c|c|c|c|c|c|}
\hline Basin & Subsection & $\begin{array}{l}500- \\
1000\end{array}$ & $\begin{array}{l}1000- \\
1500\end{array}$ & $\begin{array}{l}1500- \\
2000\end{array}$ & $\begin{array}{l}2000- \\
2500\end{array}$ & $\begin{array}{l}2500- \\
3000\end{array}$ & $\begin{array}{l}3000- \\
3500\end{array}$ & $\begin{array}{l}3500- \\
\text { Bottom }\end{array}$ \\
\hline & West Central Indian & 0.051 & -0.070 & -0.096 & -0.056 & -0.053 & -0.081 & -0.022 \\
\hline & Central Indian & 0.151 & 0.138 & 0.007 & 0.022 & -0.051 & -0.091 & -0.035 \\
\hline & East Central Indian & -0.043 & 0.037 & 0.020 & 0.031 & 0.044 & 0.020 & 0.005 \\
\hline & Southwest Indian & 0.046 & -0.214 & -0.375 & -0.342 & -0.209 & -0.128 & -0.106 \\
\hline & Southeast Indian & -0.107 & -0.051 & -0.005 & 0.020 & -0.026 & -0.059 & -0.050 \\
\hline & $\begin{array}{l}\text { West Far South } \\
\text { Indian }\end{array}$ & -0.062 & -0.104 & -0.060 & -0.045 & -0.040 & -0.078 & -0.054 \\
\hline & $\begin{array}{l}\text { Central Far South } \\
\text { Indian }\end{array}$ & -0.140 & -0.040 & 0.025 & 0.035 & 0.022 & -0.030 & -0.111 \\
\hline & $\begin{array}{l}\text { Antarctic Far South } \\
\text { Indian }\end{array}$ & 0.141 & 0.102 & 0.033 & -0.034 & -0.095 & -0.183 & -0.163 \\
\hline & $\begin{array}{l}\text { East Far South } \\
\text { Indian }\end{array}$ & 0.000 & 0.002 & 0.000 & 0.012 & 0.011 & -0.015 & -0.044 \\
\hline & Average & -0.001 & -0.022 & -0.058 & -0.046 & -0.047 & -0.071 & -0.060 \\
\hline Overall & By Volumes & -0.091 & -0.040 & -0.073 & -0.052 & -0.042 & -0.057 & -0.066 \\
\hline
\end{tabular}

North Atlantic Ocean (excluding Labrador Sea)

We examined 10 subregions of the North Atlantic Ocean. DO levels in the waters below $1500 \mathrm{dbar}-$ the layers relevant to the North Atlantic Deep Water--showed a consistent negative trend over time. Both the Northeast and North Central North Atlantic subsections had particularly strong deoxygenation in their 1500-2000 dbar and 2000-2500 dbar layers.

The 500-1000 dbar layer shows consistent deoxygenation throughout the North Atlantic, apart from North Central North Atlantic. Strongest negative trends for this layer occurred in the Northeast North Atlantic $\left(-0.317 \mu \mathrm{mol} \mathrm{kg}^{-1}\right.$ year $\left.^{-1}\right)$ and the Caribbean $\left(-0.306 \mu \mathrm{mol} \mathrm{kg}^{-1}\right.$ year $\left.^{-1}\right)$ regions. However, this layer does show a broad range of DO changes $\left(+0.151 \mu \mathrm{mol} \mathrm{kg}^{-1}\right.$ year $^{-1}$ to $-0.317 \mu \mathrm{mol} \mathrm{kg}^{-1}$ year $\left.^{-1}\right)$.

We observe the principal exception to the otherwise consistent negative DO trends in all layers of the North Atlantic in the 1000-1500 dbar layer. Although equatorial-bordering regions of the North Atlantic showed a negative trend in this layer, there is an overall positive trend in DO concentrations in the 1000$1500 \mathrm{dbar}$ layer in the remainder of the North Atlantic, averaging $+0.080 \mu \mathrm{mol} \mathrm{kg}^{-1}$ year $^{-1}$. We observed particularly notable increases in the North Central North Atlantic $\left(+0.310 \mu \mathrm{mol} \mathrm{kg}^{-1}\right.$ year $\left.^{-1}\right)$ and West North Atlantic $\left(+0.439 \mu \mathrm{mol} \mathrm{kg}^{-1}\right.$ year $\left.^{-1}\right)$. 
While there are differences, these North Atlantic's results align with those of Stendardo et al. [13]. Their investigation in the North Atlantic found deoxygenation, especially in the 500-1000 dbar layer.

Labrador Sea (Northwest North Atlantic)

The Labrador Sea matched 2016-minus-1990 cruise pair ('Northwest North Atlantic' in Figure 1) shows consistent deoxygenation in all layers except for the 3000-3500 dbar layer. In fact, in the 1000-1500 and 1500-2000 dbar layers, the Northwest North Atlantic experienced some of the largest individual rates of decrease in DO concentrations (-0.404 and $-0.538 \mu \mathrm{mol} \mathrm{kg}^{-1}$ year ${ }^{-1}$, respectively) we found for these layers in all the global subregions we examined. This is unlike the rest of the North Atlantic subregions, especially in the 1000-1500 dbar layer.

The Labrador Sea is oceanographically unique among the North Atlantic subregions due to winter convection reaching to ca. 2000 dbars plus both interannual [19] and decadal (AMOC and NAO-driven) [20] variability. Thus, varying upper layer characteristics and deep winter convection combine to bring temporal changes well into the Labrador Sea interior. Excepting single-cruise fluctuations, a time series of cruise-mean dissolved oxygen data in 500 dbar thick layers from 500 to 3500 dbar from 28 Labrador Sea cruises conducted between 1990 and 2016 (Figure 2) shows mostly consistent multi-year patterns of increases and decreases of layer mean oxygen concentrations. There are abrupt, shorter-term changes, but strong deoxygenation between 1000 to 2500 dbars is evident over the 27-year record. There is evidence in the last years of the record for reoxygenation of these layers, which warrants future exploration.

\section{South Atlantic Ocean \& Weddell Sea}

We examined 6 subregions of the South Atlantic Ocean, with results showing the most consistent temporal DO trend among the five major basins we studied. All layers in all subsections of the South Atlantic experienced deoxygenation since the 1980s (Figure 1), with especially large deoxygenation in Antarctic-bordering waters.

Each layer shows stronger deoxygenation magnitudes than those in the other principal ocean regions, with the 500-1000 dbar layer especially strong at $-0.226 \mu \mathrm{mol} \mathrm{kg}^{-1}$ year $^{-1}$. In most subregions, greatest deoxygenation is observed in the upper one or two layers.

The Weddell Sea is a crucial element of the global overturning circulation because of involvement in Antarctic Deep Water formation [21]. We found one spatially matched bottle DO section pair, though separated by only 9 years. Results from that pair suggest that the subregion experienced deoxygenation rates consistent with those of the South Atlantic, with especially noticeable deoxygenation in the 1500$2000 \mathrm{dbar}$ layer and the layer below $3500 \mathrm{dbar}$. The 2500-3000 dbar layer of the Weddell Sea is the only layer in all the South Atlantic showing an increase in DO, at a rate of $+0.098 \mu \mathrm{mol} \mathrm{kg}^{-1} \mathrm{year}^{-1}$. Interestingly, this is the depth range of impact from Weddell Sea polynyas [22]. One or more of these likely ventilated this layer locally during the interval between the cruises. 
We examined 8 subregions of the North Pacific Ocean. The North Pacific shows consistent decreases in DO in nearly all layers, like results from earlier research [17]. Note that we included the tropical Pacific Ocean subregions in the South Pacific due to regional similarities.

The 500-1000 dbar layer shows particularly large and consistent deoxygenation throughout the North Pacific, averaging $-0.218 \mu \mathrm{mol} \mathrm{kg}^{-1}$ year ${ }^{-1}$ (excluding the Bering Sea). Most North Pacific layers below $1500 \mathrm{dbar}$ also showed consistent deoxygenation, with rates clustered near the average values. There is unusually large deoxygenation in the Far West North Pacific subregion, perhaps stemming from largescale upwelling and continual remineralization of organic matter [12].

In the Bering Sea, unlike the rest of the North Pacific, we observed DO increases in the deeper layers in the Bering Sea. The layers between 1000 and 2500 dbar and below 3500 dbars all show temporal increases in DO. These observations appear to be mostly consistent with those in Sun et al. [23].

\section{Equatorial \& South Pacific Ocean}

We examined 11 subregions of the Equatorial and South Pacific Ocean.

In the tropical and mid-latitude South Pacific, waters in the 500-1000 dbar layer consistently showed increases in DO, differing from the North Pacific's strong, consistent negative temporal DO trend in the same layer. But in the southern South Pacific, like the southern portions of the South Atlantic and Indian basins, DO mostly decreased over time, especially in the East and Southeast South Pacific.

As is the case with nearly every ocean subregion we studied, South Pacific waters below $3500 \mathrm{dbar}$ showed a consistent negative temporal DO trend. For South Pacific layers between 1000 and $3500 \mathrm{dbar}$, noteworthy results include: (1) the large increase in DO in the 1000-1500 dbar layer in mid-latitude South Pacific, with Northwest, Central, and Northeast South Pacific showing an average $+0.096 \mu \mathrm{mol} \mathrm{kg}{ }^{-1}$ year $^{-1}$ increase; (2) deoxygenation continuously increasing with depth in the Farsouth South Pacific, with especially large values for oceanic layers below $3000 \mathrm{dbar}$; and (3) contrasting trends between the upper layers of the South Pacific's northeast, which show small DO increases, and southeast, where there were large DO decreases, subregions.

The Drake Passage showed strong deoxygenation in every layer between 1990 and 2009, at times offscale in Figure 1. In fact, the deoxygenation observed in the Drake Passage is the largest in magnitude in the layers between 500 and 3500 dbars across all subsections in the five basins studied (excluding the Labrador Sea). Due to these anomalously large changes, which may be the result of an unresolved data quality issue, the Drake Passage DO change results were not included in relevant average value calculations.

Indian Ocean 
We examined 10 subregions of the Indian Ocean, excluding only the northeast Indian Ocean due to lack of spatially coincident data meeting our criteria. Temporal trends in DO in the Indian Ocean are not as strongly spatially coherent as those we found in the Pacific and Atlantic Oceans. There are also no clearly observable layers that stand out over several subregions with particularly strong and/or consistent increasing or decreasing DO content.

A continuity occurs in the two layers below $3000 \mathrm{dbar}$, which display negative DO trends in every subregion but one. Four out of the 10 Indian Ocean subregions display DO increases in the 500-1000 dbar layer, with no marked geographical/regional grouping of DO changes. There is also little similarity between the behavior of the 500-1000 dbar layer and the layers below $1000 \mathrm{dbar}$, which may be a sign of independence of the waters above $1000 \mathrm{dbar}$ from those below.

\section{Discussion}

Our examination of DO data over recent decades, averaging results layer-by-layer, points to a consistent overall trend of deoxygenation below $500 \mathrm{dbar}$ of the Atlantic, Pacific, and Indian Oceans, including their Southern Ocean extensions (Figure 3). All layers in all oceans showed a temporal average decrease in DO except for the South Pacific's 500-1500 dbar and the North Atlantic's 1000-1500 dbar layers. The North Pacific and South Atlantic show strong, consistent deoxygenation across all seven examined layers, though the magnitude of deoxygenation in each layer differs between specific subregions. The Indian Ocean, while similarly consistent in its deoxygenation, interestingly has its smallest DO decrease in the 500-1000 dbar layer, perhaps due to monsoonal variations in surface conditions and stratification. The South Pacific shows overall low magnitudes of DO changes and anomalous small increases in the 500$1000 \mathrm{dbar}$ and 1000-1500 dbar layers. Finally, the North Atlantic shows a mostly similar profile to the South Atlantic except for its 1000-1500 dbar layer, which shows a small DO increase.

We prepared a global layer-by-layer summary of our results by calculating ocean-volume-weighted averages over all five oceans (Table 1; ocean volumes from publicly available NOAA datasets [24]), excluding Drake Passage for aforementioned reasons. (We used consistent weighting factors for each layer in each ocean.) All seven layers we examined experienced deoxygenation over the time periods investigated. The strongest global deoxygenation was in the 500-1000 dbar layer at $-0.091 \mu \mathrm{mol} \mathrm{kg}^{-1}$ year $^{-}$ ${ }^{1}$, while the weakest was, perhaps surprisingly, in the $1000-1500 \mathrm{dbar}$ layer at $-0.040 \mathrm{mmol} \mathrm{kg}^{-1} \mathrm{year}^{-1}$. Although the magnitudes of the deoxygenation rates appear small, there is clearly a consistent largescale decrease in global ocean DO.

Using an admittedly rough assumption that each of the 7 layers is of equal volume, we calculate an average global deoxygenation rate of $-0.060 \mu \mathrm{mol} \mathrm{kg}^{-1} \mathrm{year}^{-1}$ in the principal non-polar oceans below 500 dbar between the WOCE era of the 1900s and the present.

The highest degree of variability across the different ocean subregions was observed mostly in the 5001000 and 1000-1500 dbar layers, both of which are also layers susceptible to interannual variability due 
to more nearly direct interactions with air-sea exchange and biological mechanisms and changes. Results from waters below $3500 \mathrm{dbars}$ are especially consistent, showing deoxygenation in all but one subsection across all five basins.

The results of this study are consistent with previous studies dealing with large-scale oceanic DO trends over the last few decades [14][17][25].

Although the methodology to measure and quantify deoxygenation proposed by Schmidtko et al. [17] differs from ours, the overall trends in world ocean basins displayed by both studies are comparable and similar. Both Schmidtko's and our analyses demonstrate overall deoxygenation below $1000 \mathrm{dbars}$ for the Arctic, Equatorial Pacific, North Pacific, and far-south oceanic basins and large-scale deoxygenation in the South Atlantic Ocean spread out over the entire deep-water column. While Schmidtko et al. attribute almost $60 \%$ of the global oceanic oxygen losses to the Northern Pacific and Southern Ocean subregions, further analysis is needed in future studies to investigate if these approximations are accurate and consistent.

Stramma et al. [25] constructed a multidecadal map of the expansion of OMZs across tropical regions, estimating oxygen decrease between 300 and $700 \mathrm{dbars}$. While data in the 300-500 dbar range was not considered in our study, their results are consistent with ours in the eastern Atlantic, especially since oxygen change stabilizes closer to $0 \mu \mathrm{mol} \mathrm{kg}{ }^{-1}$ year $^{-1}$ in deeper parts of this layer. However, our relevant equatorial Pacific results are quite different, showing oxygen increases as opposed to Stramma et al.'s reported decreases. Further examination of the data sources for both analyses may be useful.

While we did not investigate causal mechanisms in our tabulation, our results are consistent with DO changes in ocean circulation resulting from reduced ventilation [17] attributed to the increased stratification of the oceans [26]. Warming which leads to stratification changes also leads to deoxygenation since warmer water has less capacity for holding oxygen [27]. These reasons, however, might not apply to explain all deoxygenation, with exceptions including multi-decadal variability as in the South Atlantic [17] and tropical Atlantic [28].

Future research can address limitations in our work. First, we chose to work exclusively in a geospatial framework which considered DO concentration on only depth/pressure as an independent variable. DO temporal trends in the geophysical domain of water masses, using temperature, salinity, and density, may be illuminating. Second, the data used here are not comprehensive, with sometimes only one matched transect pair across a large region. Third, and more serious, may be the lack of resolution of shorter-time scale variations in regional DO under sampled by the limited number of matched transects across a given region. Our calculations involve a variety of years and intervals. Results from the more frequent transects in the Labrador Sea (Figure 2) show a notable degree of interannual variability in addition to longer-term trends. While we might expect that to be the case in the upper 2500 decibars of the Labrador Sea, the question remains to what degree year-to-year fluctuations pollute the calculated long-term trends. While we argue that the consistency of deoxygenation observed across cruises in the World Ocean is not a 
coincidence, these factors still pose a limitation to the accuracy of our conclusions and hinder us from making specific predictions for future DO concentrations. It will be interesting and important to see if the bulk changes we have observed remain over future decades.

We finally note, with emphasis, that it is regrettable that there are no internationally used DO standards. This poses a challenge of unknown degree when interpreting the results. To better quantify and understand ocean deoxygenation, it is imperative to address the matter of confident standardization of DO concentration data.

\section{Conclusion}

We have identified and quantified temporal trends in dissolved oxygen concentration (DO) below 500 decibars in the principal non-polar domains of the World Ocean seen in data from repeated occupations of basin-spanning vertical sections originally conducted during WOCE. We found a persistent trend, with regional and layer-specific variations, of global multi-decadal decrease in DO, or deoxygenation. While previous studies have highlighted deoxygenation near the equator [25] and the North Atlantic [13], the analysis conducted in this study indicates that varying degrees of deoxygenation are present in almost all regions and levels below $500 \mathrm{dbars}$ of the Atlantic, Pacific, and Indian Oceans, at a global average rate of $-0.06 \mu \mathrm{mol} \mathrm{kg}^{-1}$ year $^{-1}$. Because ocean deoxygenation is a potential consequence of modern climate change, continued evaluation and improved understanding of the observed trends are necessary, especially considering its extensive environmental impacts.

\section{Methods}

To assure global scope and high data quality we used only repeated vertical sections including bottle DO data initially occupied as part of WOCE, obtained from the CLIVAR and Carbon Hydrographic Data Office (CCHDO), focusing on their oldest (typically 1988-1999) and most recent (typically 2010-2019) data. For example, we used Atlantic meridional section A16 bottle data from 1988-1989 and 2013-2014. We removed bottles without DO data from titrations, all values quality coded bad or uncertain, incomplete profiles, and off-section stations. No CTD oxygen sensor data were used. Sections were split into bathymetry-based sub-sections. For example, we made sub-sections from Atlantic sections A16 and A10 restricted to stations crossing the Brazil Basin.

We preferred at least 10 years of separation between cruise pairs. We retained somewhat shorter cruise pair time separations in the Weddell Sea, far south South Pacific, northeast and east central North Pacific because these important regions were not covered by other cruises which met our criteria.

For each spatially coincident pair of older and newer matched section segments, we mapped one onto the other and subtracted, older from newer, at 63 pressure surfaces from 0-6000 dbar using the Java OceanAtlas (JOA) application [17], yielding a vertical section of the differences, then calculated the mean difference on each pressure surface, yielding a vertical profile of the mean DO difference between the two 
years. Finally, we calculated the pressure-weighted mean DO difference from each vertical profile of differences in $500 \mathrm{dbar}$ thick layers from 500 to $3500 \mathrm{dbar}$, and for all data below $3500 \mathrm{dbar}$. The differences were divided by the number of years between the two sets of observations to produce DO rate of change results for each layer expressed in $\mu \mathrm{mol} \mathrm{kg}^{-1} \mathrm{year}^{-1}$. Where more than one matched section pair was present in a geographic domain, we averaged the DO rate of change, layer by layer, to yield one mean oxygen rate of change per layer in that domain.

For the Labrador Sea, we used DO data from 28 cruises across the AR07W transect between Canada and Greenland between 1990 and 2016, calculating a mean vertical profile from all data from each cruise, then determining pressure-weighted mean oxygen concentrations for 500 decibar thick layers from 500 to $3500 \mathrm{dbar}$.

\section{Data Availability}

The original global repeat hydrography data files are available from the CCHDO (https://cchdo.ucsd.edu). The curated matched segment data files made from those data, and used in this study, are available for download from https://joa.ucsd.edu/Data_homepage.

\section{Declarations}

\section{Acknowledgements}

The dissolved oxygen data downloaded from the CCHDO are the end result of an unending pursuit of excellence during the WOCE, CLIVAR Repeat Hydrography, and international GO-SHIP programs. Java OceanAtlas developers John Osborne and Maria Osborne equipped JOA to carry out the calculations. SIO illustrator Jennifer Matthews skillfully produced the global maps.

\section{Author Contributions}

A.A. and J.H.S. designed the research; J.H.S. obtained and processed all data for use; A.A. performed the analyses; A.A. and J.H.S. both contributed to the interpretation of the results; A.A. wrote the draft, and A.A. and J.H.S. reviewed and edited it.

\section{Competing Interests}

The authors declare no competing interests.

\section{References}

1. Diaz, R. J. \& Rosenberg, R. Spreading Dead Zones and Consequences for Marine Ecosystems. Science 321, 926-929 (2008). 
2. Matear, R. J. \& Hirst, A. C. Long-term changes in dissolved oxygen concentrations in the ocean caused by protracted global warming. Global Biogeochemical Cycles 17, (2003).

3. Keeling, R. F. \& Garcia, H. E. The change in oceanic 02 inventory associated with recent global warming. PNAS 99, 7848-7853 (2002).

4. Keeling, R. F., Körtzinger, A. \& Gruber, N. Ocean Deoxygenation in a Warming World. Annual Review of Marine Science 2, 199-229 (2010).

5. Yamamoto, A., Yamanaka, Y., Oka, A. \& Abe-Ouchi, A. Ocean oxygen depletion due to decomposition of submarine methane hydrate. Geophysical Research Letters 41, 5075-5083 (2014).

6. Bendtsen, J., Hilligsøe, K. M., Hansen, J. L. S. \& Richardson, K. Analysis of remineralisation, lability, temperature sensitivity and structural composition of organic matter from the upper ocean. Progress in Oceanography 130, 125-145 (2015).

7. Helm, K. P., Bindoff, N. L. \& Church, J. A. Observed decreases in oxygen content of the global ocean. Geophysical Research Letters 38, (2011).

8. Oschlies, A., Schulz, K. G., Riebesell, U. \& Schmittner, A. Simulated 21st century's increase in oceanic suboxia by CO2-enhanced biotic carbon export. Global Biogeochemical Cycles 22, (2008).

9. Matear, R. J., Hirst, A. C. \& McNeil, B. I. Changes in dissolved oxygen in the Southern Ocean with climate change. Geochemistry, Geophysics, Geosystems 1, (2000).

10. Bindoff, N. et al. Observations: Oceanic Climate Change and Sea Level. The Physical Science Basis. Working Group I Contribution to the Intergovernmental Panel on Climate Change Fourth Assessment Report, 385-432 (2007).

11. Jorda, G. et al. Ocean warming compresses the three-dimensional habitat of marine life. Nat Ecol Evol 4, 109-114 (2020).

12. Heinze, C. et al. The quiet crossing of ocean tipping points. PNAS 118, (2021).

13. Stendardo, I. \& Gruber, N. Oxygen trends over five decades in the North Atlantic. Journal of Geophysical Research: Oceans 117, (2012).

14. Oschlies, A., Brandt, P., Stramma, L. \& Schmidtko, S. Drivers and mechanisms of ocean deoxygenation. Nature Geosci 11, 467-473 (2018).

15. Breitburg, D. et al. Declining oxygen in the global ocean and coastal waters. Science 359, eaam7240 (2018).

16. Oschlies, A. et al. Patterns of deoxygenation: sensitivity to natural and anthropogenic drivers. Philosophical Transactions of the Royal Society A: Mathematical, Physical and Engineering Sciences 375, 20160325 (2017).

17. Schmidtko, S., Stramma, L. \& Visbeck, M. Decline in global oceanic oxygen content during the past five decades. Nature 542, 335-339 (2017).

18. Osborne, J., Swift, J. and Osborne, M. (2020). Java OceanAtlas 5.5 [Computer software]. Retrieved 11 August 2021, from https://joa.ucsd.edu. 
19. Yashayaev, I. Hydrographic changes in the Labrador Sea, 1960-2005. Progress in Oceanography 73, 242-276 (2007).

20. Rhein, M., Steinfeldt, R., Kieke, D., Stendardo, I. \& Yashayaev, I. Ventilation variability of Labrador Sea Water and its impact on oxygen and anthropogenic carbon: a review. Philosophical Transactions of the Royal Society A: Mathematical, Physical and Engineering Sciences 375, 20160321 (2017).

21. Huang, H., Gutjahr, M., Eisenhauer, A. \& Kuhn, G. No detectable Weddell Sea Antarctic Bottom Water export during the Last and Penultimate Glacial Maximum. Nature Communications 11, 424 (2020).

22. Cheon, W. G. \& Gordon, A. L. Open-ocean polynyas and deep convection in the Southern Ocean. Sci $\operatorname{Rep}$ 9, 6935 (2019).

23. Sun, X. et al. Distribution of dissolved oxygen and causes of maximum concentration in the Bering Sea in July 2010. Acta Oceanol. Sin. 33, 20-27 (2014).

24. Center, N. G. D. Volumes of the World's Oceans from ETOP01. Retrieved September 8, 2021, from https://www.ngdc.noaa.gov/mgg/global/etopo1_ocean_volumes.html.

25. Stramma, L., Johnson, G. C., Sprintall, J. \& Mohrholz, V. Expanding Oxygen-Minimum Zones in the Tropical Oceans. Science 320, 655-658 (2008).

26. Shepherd, J. G., Brewer, P. G., Oschlies, A. \& Watson, A. J. Ocean ventilation and deoxygenation in a warming world: introduction and overview. Philosophical Transactions of the Royal Society A: Mathematical, Physical and Engineering Sciences 375, 20170240 (2017).

27. Laffoley, D., \& Baxter, J. M. Ocean deoxygenation: everyone's problem (2019). Retrieved from https://portals.iucn.org/library/node/48892.

28. Brandt, P. et al. Atlantic Equatorial Undercurrent intensification counteracts warming-induced deoxygenation. Nat. Geosci. 14, 278-282 (2021).

\section{Figures}

\section{Figure 1}

Dissolved oxygen (DO) rates of change for ocean subregions. DO rates of change are calculated in $\mu \mathrm{mol}$ $\mathrm{kg}^{-1}$ year ${ }^{-1}$ for each subregion in $500 \mathrm{dbar}(\approx 500$ meter) thick layers from 500 to $3500 \mathrm{dbar}$, and below $3500 \mathrm{dbar}$. Negative rates of change (deoxygenation) are shown in blue, positive values in orange. [Table 1 includes the numerical results for each subregion and layer.]

\section{Figure 2}


Labrador Sea time series of cruise mean dissolved oxygen concentration $\left(\mu \mathrm{mol} \mathrm{kg}{ }^{-1}\right)$ in $500 \mathrm{dbar}(\approx 500$ meter) thick layers from 500 to 3500 dbar. Results from 28 Labrador Sea A01W/AR07W cruises from 1990 to 2016 are shown. All data are from bottle oxygen samples.

\section{Figure 3}

Ocean-mean dissolved oxygen rates of change (in $\mu \mathrm{mol} \mathrm{kg}^{-1}$ yearr ${ }^{-1}$ ) in $500 \mathrm{dbar}(\approx 500$ meter) thick layers from 500 to $3500 \mathrm{dbar}$, and below $3500 \mathrm{dbar}$, for the North and South Atlantic, North and South Pacific, and Indian Oceans. Negative rates of change (deoxygenation) are shown in blue, positive values in orange. 